\title{
PENGARUH MEDIA KOMUNIKASI TERHADAP INTERAKSI SOSIAL MAHASISWA/I DI LINGKUNGAN FKIP UNIKA SANTO THOMAS SU
}

\author{
Rumiris Lumban Gaol ${ }^{3}$ \\ Surel: rumiris02lumbangaol@yahoo.co.id
}

\begin{abstract}
Abstrak
Dengan berbagai layanan yang di ada handphone mahasiswa diluar jam perkuliahan lebih memilih memainkan handphonenya dari pada berbicara atau berdiskusi dengan temannya. Tujuan penelitian ini adalah untuk 1)Mengidentifikasi penggunaan media komunikasi pada mahasiswa di kampus FKIP Unika Santo Thomas SU. 2)Menganalisis faktor-faktor apa saja yang mempengaruhi dalam media komunikasi pada mahasiswa di kampus FKIP Unika Santo Thomas SU, dan 3)Menganalisis pengaruh penggunaan media komunikasi pada mahasiswa/i terhadap interaksi sosial mahasiswa/i di kampus FKIP Unika Santo Thomas SU. Penelitian ini adalah penelitian deskriptif dengan menggunakan pendekatan kuantitatif. Berdasarkan hasil pembahasan dan pengolahan data yang dilakukan maka Ha diterima, dengan demikian hasil dari 0,783 itu signifikan. Terdapat pengaruh yang positif dan signifikan antara variabel bebas (XI) yaitu media komunikasi terhadap variabel terikat (Y) yaitu interaksi sosial. Kesimpulan ini memberikan pengertian bahwa semakin banyak waktu yang dilakukan mahasiswa untuk menggunakan media komunikasi baik berupa handphone/ipad dan laptop, maka semakin berkurang atau sedikit waktu yang mereka gunakan untuk berinteraksi dengan teman di lingkungan kampus Unika Santo Thomas SU.
\end{abstract}

Kata kunci :Media Komunikasi, Handhone/Ipad/laptop, Interaksi.

\section{PENDAHULUAN}

Media komunikasi yang paling praktis adalah handpone. Handphone memiliki banyak sekali manfaat, terlebih pada saat-saat ini banyak sekali pengguna handphone pintar yang memiliki kecanggihan yang lebih banyak dari handphone biasa. Handphone dapat digunakan untuk melakukan obrolan dengan tulisan atau teks dengan aplikasi mengobrol seperti BBM, What's App, Line, We Chat dan lain sebagainya. Handphone juga dapat digunakan sebagai media bertukar gambar dan suara melalui aplikasi mengobrol tersebut. Selain itu kegunaan lain dari benda ini adalah dapat digunakan untuk bekerja terutama bagi yang membutuhkan layanan email yang dapat diakses dimana saja dan kapan saja. Definisi handphone dan kegunaannya memang sangatlah menarik.Anda juga dapat menggunakannya untuk mendengarkan musik, mengambil gambar dan merekam video di momen-momen tertentu.

${ }^{3}$ PGSD Universitas Santo Thomas S.U 
Hampir dalam setiap kegiatannya, manusia selalu bersinggungan dengan handphone.Hanphone mampu memasuki seluruh strata kehidupan manusia. Beragam alasan diutarakan manusia dalam keterikatannya dengan handphone, namun satu hal yang pasti bahwa handphone dianggap sebagai salah satu media komunikasi yang paling efektif.Mengapa demikian? Hal yang paling mendasar adalah handphone praktis untuk dibawa karena bentuknya yang kecil dan juga memiliki banyak layanan

Banyak fenomena dimana tidak jarang individu lebih memilih memainkan atau menggunakan ponselnya, meskipun ia berada ditengah-tengah suatu kegiatan atau sosialisasi dengan orang-orang disekitarnya.

Dengan berbagai layanan yang di ada handphone mahasiswa diluar jam perkuliahan lebih memilih memainkan handphonenya dari pada berbiraca atau berdiskusi dengan temannya. Dari sekian kelebihan yang telah ditawarkan dari suatu ponsel, tetapi terdapat juga banyak dampak negatif bermunculan, salah satunya adalah berkurangnya tingkat interaksi sosial antar mahasiswa di lingkungan kampus.Tujuan penelitian ini adalah untuk 1)Mengidentifikasi penggunaan media komunikasi pada mahasiswa di kampus FKIP Unika Santo Thomas SU. 2)Menganalisis faktor-faktor apa saja yang mempengaruhi dalam media komunikasi pada mahasiswa di kampus FKIP Unika Santo Thomas SU, dan 3)Menganalisis pengaruh penggunaan media komunikasi pada mahasiswa/i terhadap interaksi sosial mahasiswa/i di kampus FKIP Unika Santo Thomas SU

\section{METODE PENELITIAN}

Penelitian ini adalah penelitian deskriptif dengan menggunakan pendekatan kuantitatif.Pendekatan kualitatif dilakukan dengan analisis isi dari hasil wawancara dalam hal pengaruh media komunikasi terhadap interaksi mahasiswa di kampus. Pendekatan kuantitatif dilakukan dengan metode test melalui angket untuk pengambilan data dalam menganalisis tingkat sosialisasi mahasiswa.

\section{Variabel Penelitian}

Variabel yang di ukur daalam penelitian ini adalah

Variabel bebas dalam penelitian ini adalah media komunikasi (Variabel $\mathrm{X}_{1}$ )

Variabel terikat dalam penelitian ini adalah interaksi sosial mahasiswa

(Variabel Y).

\section{Teknik Pengumpulan Data}

\section{Observasi}

Observasi sebagai pengamatan dan pencatatan dengan sistematis terhadap fenomena-fenomena yang diselidiki dalam arti yang luas, observasi tidak terbatas pada pengamatan yang dilakuakan baik langsung maupun tidak langsung. 


\section{Wawancara atau Interview}

Wawancara adalah suatu percakapan yang digunakan untuk memperoleh data dan informasi dengan bertanya langsung kepada responden.Kuesioner.

3.Kuesioner yaitu cara pengumpulan data dengan melakukan penyebaran daftar pertanyaan kepada responden yang berhubungan dengan hasil yang diteliti.

4. Dokumentasi

Metode dokumentasi merupakan metode pengumpulan data yang sudah didokumentasikan.dengan hal-hal yang akan diteliti.

\section{Teknik Analisis Data}

Dalam analisa data menggunakan rumus Regresi sederhana dengan rumus yang telah ditentukan. Dengan norma keputusan sebagai berikut a. Jika sig $<0,05$ maka $\mathrm{H}^{\mathrm{a}}$ diterima dan $\mathrm{H}^{\circ}$ ditolak b. Jika sig $>0,05$ maka $\mathrm{H}^{\text {a }}$ ditolak dan $\mathrm{H}^{\circ}$ diterima.

\section{HASIL PENELITIAN DAN PEMBAHASAN}

Setelah melakukan penelitian melalui penyebaran angket, pengumpulan data melalui observasi dan dokumentasi di lapangan, terlebih dahulu disajikan bentuk data guna memperlancar langkah suatu penelitian

\section{Tabel Kerja Koefisien Pengaruh Media Komunikasi terhadap Interaksi Sosial Mahasiswa}

\begin{tabular}{|l|l|l|l|l|l|}
\hline No & X & Y & X.Y & $\mathbf{X}^{2}$ & $\mathbf{Y}^{2}$ \\
\hline & & & & & \\
Jumlah & 1844 & 1650 & 92288 & 103534 & 84266 \\
\hline
\end{tabular}

Berdasarkan hasil penelitian yang telah dilakukan dengan jumlah responden $(\mathrm{N})$ 33 diperoleh $r$ hitung adalah 0,783 sedangkan $r$ tabel adalah 0,344 . Ketentuan bila $\mathrm{r}$ hitung lebih kecil dari $\mathrm{r}$ tabel, maka Ho diterima, dan Ha ditolak. Tetapi sebaliknya bila $r$ hitung lebih besar dari $r$ tabel $(r h>r t)$ maka Ha diterima. Dari hasil tampak bahwa $r$ hitung lebih besar dari $r$ tabel maka Ha diterima, dengan demikian hasil dari 0,783 itu signifikan. Terdapat pengaruh yang positif dan signifikan antara variabel bebas $\left(\mathrm{X}_{1}\right)$ yaitu media komunikasi terhadap variabel terikat $(\mathrm{Y})$ yaitu interaksi sosial.

Selain juga dari hasil perhitungan yang sudah dianalisis, sesuai dengan hasil tes angket bahwa hampir $99 \%$ mahasiswa memiliki handhone, berdasarkan hasil pengamatan penulis juga menemukan bahwa keberadaan media komunikasi seperti handphone/ipad dan laptop merupakan bagian yang sangat penting yang tidak dapat dipisahkan dari mahasiswa bahkan sudah menjadi kebutuhan 
mahasiswa sehari-hari. Setelah perkuliahan selesai hal yang terlebih dahulu dilakukan adala memeriksa handphone/ipad untuk meliahat apakah ada pesan masuk, melihat berita terbaru, bahkan meng update stutus baru dengan kebebasan ekpresi yang mereka alami.

Bahkan peneliti juga melihat melalui pengamatan ketika mahasiswa berkumpul di taman kampus, mereka berkumpul bukan untuk saling berinteraksi dengan sesama teman tetapi mereka sibuk dengan media komunikasi masingmasing seperti handphone/ipad dan laptop. Mereka terlihat lebih senang berinteraksi di media sosial dibandingkan berinteraksi dengan teman mereka sendiri, mereka mencoba menunjukkan ekspresi yang berbeda ketika mencoba membuka akun media masing-masing yaitu dengan ekspresi tertawa, terkejut, sedih, iba, marah bahkan aja juga kesal atau bahkan menjengkelkan.

Keberadaan media komunikasi mampu menggantikan kebutuhan interaksi dengan teman dan lingkungan mereka sehari-hari.Disaat mereka ingin menyampaikan atau bertanya kepada seseorang mereka tidak membutuhkan waktu untuk bertemu atau tatap muka tetapi cukup melalui handphone. Sepertinya mahasiswa tampa media komunikasi hampa dalam menjalani hari-harinya.

\section{SIMPULAN}

Berdasarkan hasil pembahasan dan pengolahan data yang telah dilakukan peneliti yaitu yang berjudul pengaruh media komunikasi terhadap inetaksi sosial mahasiswa/i di lingkungan FKIP Unika Santo Thomas SU maka penulis membuat kesimpulan bahwa media komunikasi berpengaruh terhadap interaksi sosial dimana, berdasarkan penelitian yang telah dilakukan di lapangan bahwa dari analisis data yang telah dilakukan dengan jumlah responden (N) 33 diperoleh $r$ hitung adalah 0,783 sedangkan $r$ tabel adalah 0,344.Ketentuan bila $r$ hitung lebih kecil dari $r$ tabel, maka Ho diterima, dan Ha ditolak. Tetapi sebaliknya bila $r$ hitung lebih besar dari $\mathrm{r}$ tabel $(\mathrm{rh}>\mathrm{rt}$ ) maka Ha diterima. Dari hasil tampak bahwa $r$ hitung lebih besar dari $r$ tabel maka Ha diterima, dengan demikian hasil dari 0,783 itu signifikan. Terdapat pengaruh yang positif dan signifikan antara variabel bebas $\left(\mathrm{X}_{1}\right)$ yaitu media komunikasi terhadap variabel terikat $(\mathrm{Y})$ yaitu interaksi sosial. Kesimpulan ini memberikan pengertian bahwa semakin banyak waktu yang dilakukan mahasiswa untuk menggunakan media komunikasi baik berupa handphone/ipaddan laptop, dimana kugunaan media komunikasi tersebut mereka gunakan mencari hiburan, fasion, game, bahkan berinteraksi melalui akun media sosial seperti facebook, twitter, line, whatsapp, wechat, bbm dan lain sebagainya, maka semakin berkurang atau sedikit waktu yang mereka gunakan untuk berinteraksi dengan teman di lingkungan kampus Unika Santo Thomas SU. 


\section{DAFTAR RUJUKAN}

Anas Sudjiono, 2006: Pengantar Evaluasi Pendidikan, Jakarta: RajaGrafindo Persada.

Didik M.Arief Mansur 2005, Cyber Law Aspek Hukum Teknologi Informasi, Bandung : PT Rapfika Aditama,.

Badwilan, Rayyan Ahmad. 2004, Rahasia Dibalik Handphone.Jakarta : Darul Falah.

Brotosiswoyo, B. Suprapto.2002, 'Dampak Sistem Jaringan Global Pada Pendidikan Tinggi: Peta Permasalahan'. Komunika. No 28/IX. Tangerang : Universitas Terbuka.

Budyatna, M. 2005, 'Pengembangan Sistem Informasi : Permasalahan Dan Prospeknya'.Komunika.

Fiati, Rina. 2005, Akses Internet Via Ponsel. Yogyakarta : Penerbit Andi Yogyakarta.

Internet fundamentl

(http://kalamkata.org/ebook/indonesian/Modul01 internetfundamental.pdf, akses 23 Nopember 2015).

Gerungan, W.A.4004, Psikologi Sosial. Bandung : PT Refika Aditama.

Kenali Pengertian Mahasiswa Dan Menurut Para Ahli (http://www.pengertianku.net/2014/11/kenali-pengertian-mahasiswa-danmenurut-para-ahli.html) diakses pada 18 November 2015

Nurudin. 2005, Sistem-Sistem Komunikasi di Indonesia. Jakarta : PT Raja Grafindo Persada.

Ronny Kountur, 2003, Metode Untuk Penulisan Skripsi \& Tesis, Jakarta: CV.Taruna Grafika Cetakan 1

Saydam, Gouzali.2005, Teknologi Telekomunikasi, Perkembangan dan Aplikasi.Bandung: Alfabeta.

Sarwono, Sarlito Wirawan. 2002, Psikologi Sosial, Individu dan Teori-teori Psikologi Sosial.Jakarta: Balai Pustaka.

Soekanto, Soerjono, 2002 . Sosiologi Suatu Pengantar. Jakarta : PT RajaGrafindo.

Suharsimi Arikunto, 1992 Cet. Ke X : Prosedur Penelitian Suatu Pendekatan Praktik, Jakarta: PT Rineka Cipta. 
